\title{
Preserving History for Effective Urban Planning in the Globalizing World
}

\author{
Nkeiru Hope Ezeadichie* \\ Department of Urban and Regional Planning, University of Nigeria, Nigeria
}

Submission: March 21, 2017; Published: June 14, 2017

*Corresponding author: Ezeadichie N, Department of Urban and Regional Planning, University of Nigeria, Enugu Campus, Enugu, Nigeria, Tel: +2348068820482; Email: nkeiru.ezeadichie@unn.edu.ng

\begin{abstract}
The evolution of the world is currently at the point of globalization, turning the world to a global village where there is escalation of hybrid cultural and value system. However some nations realizing the importance of history have made it mandatory in their school curricula to preserve their values. Regrettable, some African nations like Nigeria places little or no value on this generational equipping and moulding tool. This paper advocates for reinstating of history in Nigerian secondary schools and also urges urban planners who manage our cities to re-strategize to make the study and preservation of our heritage more relevant in the current global village.
\end{abstract}

Keywords: Preserving; History; Planning; Globalization

\section{Introduction}

The current world has been evolving from one stage to a better stage in terms of many aspects of life and this trend is bound to continue since the only constant thing is change. Many factors have facilitated the changes in our contemporary world namely; urbanisation, modernisation and the most current globalisation. Urbanisation trend had its effect in the global North in the eighteenth century and has now shifted to the global South operating as rapid urbanisation. Urbanisation in sub-Saharan Africa in general and Nigeria in particular, is characterised by rapid urban population growth stimulated by rural-urban migration and natural increase [1]. A notable feature of African, especially Nigerian urbanisation is crave for foreign goods and services at the expense of our local and natural resources, cultural values and beliefs. This crave has affected every aspect of our lives both positively and negatively. The current globalization trend which merges the world to a global village has escalated the level of both access and imbibing of foreign goods and values. Definitely there are many positive effects of these urbanisation and globalization trend yet one major negative effect is the loss of our values, beliefs and history. The lack of value for Nigerian history has been growing with each new generation. This lack of value for history denies the individuals and the nation as a whole the great benefits of studying and valuing history. This paper is therefore a call for the recognition, increased valuing, planning and re-packaging of our history and heritage as tourism resource for increased benefit and most especially economic benefit in the current global economic crisis.

\section{Human History}

Human existence on earth can be classified into the prehistory era, about 5 million years ago [2] and the recorded history era that started about 5,000 years ago [3]. The prehistory entails the Stone Age, the Neolithic era and most part of the Bronze era while the recorded history era consists of the Classical Age, the Medieval Age, the Renaissance period, Enlightenment period, the Industrial Age and the Modern Era, in which we currently live. Understanding and explaining the contemporary behavioural patterns of man as well as predicting tomorrow's pattern depends to some extent on the knowledge of man's activities at each development period. As such the importance of history cannot be over emphasized.

\section{Relevance of History}

The study of history informs us how and why things change as well as the resilient components of a changing society [4]. History models 'certifiable heroes' [4] to the present generation with many lessons on various issues of life-diligence, courage and tackling challenges of life. In this era of globalisation when many cultural values have continued to be depleted; the preservation of our history, beliefs and values can point the present generation back to our original values despite the overriding foreign values all around us. Preserving our history is therefore expedient.

\section{Preserving History}

Preservation has been described as the guarding of cultural assets to ensuring extended life span. The preservation of the 
history of any society is an indispensable factor for patriotism and can best be achieved by the inclusion of history in the educational curricula. This explains why America insists on the inclusion of history in its school curricula and turns out patriotic citizens unlike some developing countries like Nigeria that has no value for history in its school curricular and is replete with corrupt and unpatriotic citizens. In a survey of undergraduate students of an urban planning department in a Nigerian University; 5 out of 63 sampled students (7.94\%) did history in their secondary school. Half of the sampled students indicated their secondary schools did not offer history as a subject while about 30\% disclosed that they simply disliked history, terming it as boring, voluminous and complex. Undergraduate urban planning students are supposed to be the planners of our future cities, yet they despised the knowledge of history which should have given them the required knowledge on trends of development.

\section{Effective Future Urban Planning Based on Historical Knowledge}

Urban planning which orders the use of land and urban spaces has a major role in the kind of future cities that will emerge. Planning of cities especially in the global South at this period of globalisation has become a huge change and requires more knowledge and strategies than ever before. The challenges of the global South cities-poverty, high rate of unemployment and the global economic crises necessitates innovative urban planning. Innovative planning can preserve and re-package our history and cultural heritage to ensuring a more value and knowledge-based future generation. The preservation and repackaging of our history and cultural heritage will re-position our tourism sector especially in the oil-based economy of Nigeria as an alternative source of revenue in the global economic crisis.

\section{Conclusion and Recommendations}

This paper advocates that the preservation and study of history is a veritable foundation for planning better future cities. The paper recommends that the study of history be emphasized in the school curricular for more patriotic citizenship and our cultural heritage be re-packaged as tourism resource for diversified and increased economic revenue like many other nations.

\section{References}

1. Onodugo VA, Ezeadichie NH, Onwuneme CA, Anosike E A (2016) The dilemma of managing the challenges of street vending in public spaces: The case of Enugu City, Nigeria 59: 95-101.

2. Le Gates RT, Stout F (2000) Modernism and Early Urban Planning. In: Le Gates RT \& Stout F (Eds.), The City Reader. Taylor and Francis Group, New York, USA.

3. Adinnu IF (2005) Physical Planning in History. Jube-Evans books and publications, Bida, Nigeria.

4. Stearns PN (1998) Why Study History? American Historical Association, Washington, USA.

\section{Your next submission with Juniper Publishers will reach you the below assets}

- Quality Editorial service

- Swift Peer Review

- Reprints availability

- E-prints Service

- Manuscript Podcast for convenient understanding

- Global attainment for your research

- Manuscript accessibility in different formats

( Pdf, E-pub, Full Text, Audio)

- Unceasing customer service

Track the below URL for one-step submission https://juniperpublishers.com/online-submission.php 